Ambariani. : Pengaruh Kualitas Pelayanan Puskesmas Santun Lansia Pada Kepuasan Pasien Lanjut Usia Di Puskesmas Santun Lanjut Usia Kabupaten Bogor Jawa Barat 
Ambariani. : Pengaruh Kualitas Pelayanan Puskesmas Santun Lansia Pada Kepuasan Pasien Lanjut Usia Di Puskesmas Santun Lanjut Usia Kabupaten Bogor Jawa Barat

60 | IJEMC, Volume 1 No. 1, Desember 2014 


\title{
Pengaruh Kualitas Pelayanan Puskesmas Santun Lansia Pada Kepuasan Pasien Lanjut Usia Di Puskesmas Santun Lanjut UsiaKabupaten Bogor Jawa Barat
}

\author{
Ambariani, ${ }^{1}$ Gaga Irawan, ${ }^{2}$ Herry Garna, ${ }^{3}$ Farid Husin, ${ }^{4}$ Tita Husnitawati Madjid, ${ }^{5}$ Hadyana Sukandar ${ }^{6}$ \\ ${ }^{1}$ Mahasiswa Program Studi Magister Kebidanan Fakultas Kedokteran Universitas Padjadjaran, \\ ${ }^{2}$ Departemen Ilmu Gizi Fakultas Kedokteran Universitas Padjadjaran, \\ ${ }^{3}$ Departemen Ilmu Kesehatan Anak Fakultas Kedokteran Universitas Padjadjaran \\ ${ }^{5}$ Departemen Obstetri dan Ginekologi Fakultas Kedokteran Universitas Padjadjaran \\ ${ }^{6}$ Departemen Epidemiologi dan Biotatistik Fakultas Kedokteran Universitas Padjadjaran
}

\begin{abstract}
Abstrak
Peningkatan jumlah lansia membawa dampak pada permasalahan kesehatan dan ekonomi.Keadaan ini disebabkan penduduk lansia mengalami kemunduran fisik secara alamiah sehingga tidak mampu mandiri dalam pemenuhan kebutuhan hidup. Kesehatan yang baik merupakan kunci bagi lansia untuk dapat tetap mandiri dan berperan dalam kehidupan keluarga dan di tengah masyarakat.Program Puskesmas Santun Lansia yang dicanangkan sejak tahun 2003 untuk memenuhi kebutuhan pelayanan kesehatan lansia agar tercapai kualitas hidup lansia yang sehat dan mandiri.Tujuan penelitian adalah untuk mengetahui pengaruh kualitas pelayanan pada kepuasan pasien lanjut usia di Puskesmas Santun Lanjut Usia Kabupaten Bogor Jawa Barat.Penelitianini menggunakan metode explanatory survey untuk meneliti lebih jauh pengaruh kualitas pelayanan Puskesmas Santun Lansia pada kepuasan pasien lansia. Penelitian dilakukan melalui suatu instrumen survei yang mengandung pertanyaan mengenai kualitas pelayanan, dengan menggunakan pendekatan teori servqual dari Parasuraman. Subjek penelitian berjumlah 100 pasien lansia dari bulan Oktober-Desember 2013. Hasil survei dianalisis dengan Uji Kruskal-Wallis, Mann-Whitney, dan regresi berganda.Hasil penelitian menunjukkan bahwakualitas pelayanan Puskesmas Santun Lansia (dimensi bukti fisik, ketanggapan, dan perhatian) mempunyai pengaruh pada kepuasan pasien lansia $(\mathrm{p}<0,05)$. Besar pengaruh bukti fisik 0,42 (17,6\%), ketanggapan 0,28 (7,8\%), dan perhatian 0,25 (6,3\%). Dimensi pelayanan lainnya (kehandalan dan jaminan) tidak terbukti berpengaruh ( $>0,05)$. Variabel sosio-demografik (usia dan pendidikan) berbeda signifikan dengan skor kepuasan pasien lansia $(\mathrm{p}<0,05)$.Kualitas pelayanan Puskesmas Santun Lansia dalam dimensi servqual (bukti fisik, kehandalan, ketanggapan, jaminan, dan perhatian) telah dipersepsikan memiliki kenyataan cukup baik, walaupun kualitas pelayanan yang diterima masih belum memenuhi harapan.
\end{abstract}

Kata kunci: Kepuasan pasien lansia, kualitas pelayanan, puskesmas santun lansia

Korespondensi: Jl. Karya Bhakti No. 3 Cibubur, mobile (021) 8730818/ HP 087722363669,

e-mail:ambarianihari@gmail.com 


\title{
The Effect Of Healthcare Services Quality On Elderly Patient Satisfaction In Public Health Center Mannered Elderly In District Bogor Of West Java
}

\begin{abstract}
An increasing number of elderly in population have an impact on the health and economic problems. These circumstances due to physical decline in the elderly and is unable to naturally self-sufficient in fulfilling the needs of their own lives. Good health is the key for the elderly to remain independent and play a role in family life and in society. Mannered elderly health center's program launched in 2003 to fulfill the health care needs of the elderly in order to achieve the quality of life of elderly healthy and independent. The design of this study is an explanatory survey method to asses quality of mannered elderly health center services which effected on satisfaction of elderly patients. The study was conducted through a survey instrument consisting questions about the quality of service by using the theories of Parasuraman (servqual). Subjects of the study were 100 elderly patients who had visited mannered elderly health centers in October-December 2013. Several socio-demographic variables were included in the study. Kruskal-Wallis test, Mann-Whitney test and multiple regression analyses, were applied in the study. The results indicates that services quality (tangibles dimension, responsiveness and empathy) of mannered elderly health center had a statistically significant effect on satisfaction of elderly patients $(\mathrm{p}<0.05)$. The dimension of tangibles has influenced on satisfaction; $0.42(17.6 \%)$, and responsiveness; 0.28 (7.8\%), and empathy; $0.25(6.3 \%)$. While the other dimensions of services quality (reliability and assurance) had not a statistically significant effect. Further, some of elderly patients's socio-demographic (age and education) were found to have a statistically significant difference on their satisfaction's score $(p<0.05)$. The service quality of mannered elderly health center in servqual dimensions (tangibles, reliability, responsiveness, assurance, and empathy) have been perceived to have a reality quite well. Despite this fact the quality of care received is still not meet the patient's expectations for the fifth dimension.
\end{abstract}

Keywords: Satisfaction elderly patients, service quality, mannered elderly health centers 


\section{Pendahuluan}

Peningkatan UHH secara global, menyebabkan populasi penduduk dengan kelompok lansia bertambah menjadi dua kali lipat. Indonesia termasuk negara dengan jumlah lansia terbanyak kelima di dunia pada tahun 2000yaitu sebanyak 15,3 juta orang dan meningkat menjadi 18,1 juta orangpada tahun $2010 .^{1-5}$ Peningkatan ini berdampak pada permasalahan kesehatan dan ekonomi yang merupakan permasalahan utama penduduk lansia. ${ }^{1-4}$ Keadaan ini disebabkan penduduk lansia mengalami kemunduran fisik secara alamiah sehingga tidak mampu mandiri dalam pemenuhan kebutuhan hidup. Kesehatan yang baik merupakan kunci bagi lansia untuk dapat tetap mandiri serta berperan dalam kehidupan keluarga dan di tengah masyarakat. Untuk meningkatkan kualitas hidup lansia, maka pemerintah mengeluarkan suatu kebijakan perlindungan lansia yang salah satunya dengan pengadaan program puskesmas yang santun bagi lansia yang mulai dicanangkan sejak tahun $2003 .^{3-5}$ Di Kabupaten Bogor, program ini baru diterapkan oleh 12 puskesmas dari total 40 puskesmas. ${ }^{6}$

Tantangan yang dihadapi dalam upaya peningkatan kesehatan dan kesejahteraan lansia ini adalah sarana dan prasarana pelayanan kesehatan masih terbatas memberikan layanan yang ramah dan mudah diakses oleh lansia. ${ }^{1,3-5}$ Kepuasan pasien merupakan salah satu ukuran suksesnya pelayanan kesehatan., ${ }^{7,811}$ Kepuasan pasien bergantung pada banyak faktor, seperti kualitas pelayanan klinis, ketersediaan obat, perilaku tenaga kesehatan dalam pelayanan, infrastruktur tempat pelayanan, kenyamanan secara fisik, dukungan emosional, dan menghargai kesukaan pasien. ${ }^{7-14}$ Ketimpangan antara harapan dan layanan yang diterima pasien berhubungan dengan penurunan kepuasan. ${ }^{10,12}$ Kepuasan pasien terhadap kualitas pelayanan merupakan konsep dominan dalam jaminan kualitas dan program peningkatan kualitas. Pasien lansia merupakan pengguna jasa pelayanan kesehatan dan kelompok pasien yang penting dengan adanya pengembangan kebijakan pelayanan kesehatan. ${ }^{11,15}$

Dari uraian tersebut, maka sangat penting dilakukan penelitian ini untuk mengetahui pengaruh kualitas pelayanan pada kepuasan pasien lanjut usia di Puskesmas Santun Lanjut Usia Kabupaten Bogor Jawa Barat.

\section{Metode}

Penelitian dilakukan dengan menggunakan rancangan metode survei analitik untuk meneliti pengaruh kualitas pelayanan Puskesmas Santun Lansia pada kepuasan pasien lansia. Data dikumpulkan secara potong lintang, yaitu pengambilan data semua objek penelitian yang dikumpulkan secara langsung dari responden melalui kuesioner dalam satu kali pengambilan. ${ }^{16-19}$

Pengukuran kualitas pelayanan Puskesmas Santun Lansia penelitian ini menggunakan pendekatan konsep servqual, yaitu meliputi dimensi bukti fisik, kehandalan, ketanggapan, jaminan, dan perhatian. ${ }^{20}$ Bukti fisik merupakan gambaran nyata yang ditampilkan oleh puskesmas, sedangkan kehandalan merupakan kemampuan puskesmas dalam memberikan pelayanan secara akurat dan tepat merupakan unsur penting yang mampu memberikan kepuasan kepada pasien. Dimensi lain yang juga penting dalam memberikan kepuasan kepada pelanggan adalah ketanggapan, jaminan, dan perhatian petugas. Kualitas dipersepsikan baik, apabila petugas memiliki perhatian, rasa menghargai, peka serta memiliki kemampuan secara cepat dan tepat dalam menanggapi keluhan maupun memberikan informasi sesuai kebutuhan pasien. ${ }^{15,21-23}$ Pengukuran persepsi pasien lansia terhadap kualitas pelayanan kesehatan di Puskesmas Santun Lansia menggunakan skala ordinal. Kepuasan pasien lansia didefinisikan sebagai kesesuaian kualitas pelayanan yang diterima dengan yang diharapkan oleh pasien lansia. ${ }^{24}$ Pengukuran kepuasan pasien lansia terhadap pelayanan kesehatan di Puskesmas Santun Lansia menggunakan rasio skor kenyataan dibandingkan dengan skor harapan responden untuk lima dimensi pelayanan (bukti fisik, kehandalan, ketanggapan, jaminan, dan perhatian). ${ }^{10,12,25}$

Analisis statistik untuk mengetahui pengaruh variabel kualitas pelayanan Puskesmas Santun Lansia (bukti fisik, kehandalan, ketanggapan, jaminan, dan perhatian) pada kepuasan pasien, menggunakan regresi multivariabel. Prosedur statistik ini digunakan untuk mencari koefisien jalur (besar kontribusi) variabel penyebab (X) pada variabel akibat (Y). ${ }^{19}$ Penelitian dilaksanakan di Puskesmas Ciawi untuk melaksanakan program Puskesmas Santun Lansia di Kabupaten Bogor pada bulan 
Oktober 2013-Januari 2014. Jumlah sampel yang diperoleh adalah 100 orang. Peneliti menggunakan asumsi bahwa perbedaan lokasi dan kondisi 12 Puskesmas Santun Lansia yang tersebar di Kabupaten Bogor bersifat konstan dalam kualitas pelayanan sehingga tidak dimasukkan sebagai variabel penelitian, sehingga pengambilan sampel hanya di satu Puskesmas Santun Lansia, yaitu Puskesmas Ciawi yang merupakan pilot project program Puskesmas Santun Lansia di Kabupaten Bogor pada tahun 2012.

Tabel 1. Gambaran Kualitas Pelayanan Puskesmas Santun Lansia dan Kepuasan Pasien Lansia

\section{Hasil}

Berdasarkan hasil penelitianpada Tabel 1 yang menunjukkan bahwa kepuasan belum mendekati skor ideal kepuasan $100 \%$, diduga terkait dengan persepsi responden yang menilai kualitas dimensi pelayanan Puskesmas Santun Lansia tidak sesuai dengan harapan mereka. Pelayanan Puskesmas Santun Lansia dirasakan cukup oleh responden yang ditunjukkan oleh skor kepuasan yang lebih besar dari $70 \%$. Fakta ini mengindikasikan bahwa layanan Puskesmas Santun Lansia harus segera ditingkatkan melalui upaya perbaikan pelayanan secara bertahap.

\begin{tabular}{llll}
\hline \multirow{2}{*}{ Dimensi Kualitas Pelayanan } & \multicolumn{2}{l}{ Total Skor Rata-rata } & \\
\cline { 2 - 3 } & Harapan & Kenyataan & Kepuasan $(\%)$ \\
\hline Bukti fisik & 23,09 & 17,65 & 76,6 \\
Kehandalan & 23,48 & 16,77 & 71,5 \\
Ketanggapan & 23,46 & 19,31 & 82,3 \\
Jaminan & 23,45 & 19,99 & 85,1 \\
Perhatian & 23,07 & 19,11 & 82,9 \\
\hline Rata-Rata & 23,31 & 18,57 & 79,7 \\
\hline
\end{tabular}

Hasil penelitian menunjukkan bahwa dimensi kehandalan mempunyai skor kenyataan berada di bawah rata-rata, sedangkan skor harapannya berada di atas rata-rata. Hal ini mengindikasikan bahwa dimensi kehandalan merupakan dimensi yang harus diprioritaskan untuk segera diperbaiki pelaksanaannya. Prioritas perbaikan selanjutnya setelah kehandalan yaitu dimensi bukti fisik karena kenyataannya dipersepsikan di bawah rata-rata meskipun harapannya juga di bawah ratarata.Selain itu, dimensi bukti fisik dalam pelayanan Puskesmas Santun Lansia perlu lebih disosialisasikan keuntungannya dibandingkan dengan puskesmas lainnya kepada masyarakat lansia untuk meningkatkan harapannya.Dimensi perhatian menempati prioritas perbaikan ketiga setelah bukti fisik. Perbaikan dimensi perhatian sebaiknya ditekankan kepada upaya sosialisasi yang lebih baik kepada masyarakat lansia meningkatkan harapannya. Dimensi ketanggapan dan jaminan merupakan dimensi kualitas pelayanan yang pelaksanaannya harus dipertahankan karena memiliki kenyataan dan harapan yang di atas rata-rata kualitas pelayanan. Keseluruhan perbaikan pelaksanaan dimensi kualitas pelayanan harus ditingkatkan secara bertahap sesuai dengan kemampuan Puskesmas Santun Lansia.

Berdasarkan hasil pada Tabel 2 diperoleh skor kepuasan pasien lansia memiliki perbedaan yang signifikan secara statistik berdasarkan perbedaan karakteristik usia dan pendidikan. 
Ambariani. : Pengaruh Kualitas Pelayanan Puskesmas Santun Lansia Pada Kepuasan Pasien Lanjut Usia Di Puskesmas Santun Lanjut Usia Kabupaten Bogor Jawa Barat

Tabel 2 Hubungan Skor Kepuasan dengan Karakteristik Pasien Lansia

\begin{tabular}{|c|c|c|c|c|c|}
\hline \multirow[b]{2}{*}{ Karakteristik } & \multirow[b]{2}{*}{$\mathbf{n}$} & \multicolumn{2}{|c|}{$\begin{array}{l}\text { Skor Kepuasan Pasien (Skala- } \\
\text { 100) }\end{array}$} & \multirow{2}{*}{$\begin{array}{l}\text { Statistik } \\
\text { Uji }\end{array}$} & \multirow[b]{2}{*}{ Nilai p } \\
\hline & & Fonatis & SD & & \\
\hline \multicolumn{6}{|l|}{ Jenis kelamin } \\
\hline Perempuan & 70 & 80,89 & 13,5 & \multirow[t]{3}{*}{$-0,95^{\mathrm{a}}$} & \multirow[t]{3}{*}{0,343} \\
\hline Laki-laki & 30 & 78,43 & 10,9 & & \\
\hline Usia (tahun) & & & & & \\
\hline $60-70$ & 72 & 82,05 & 12,1 & \multirow[t]{3}{*}{$-2.09^{\mathrm{a}}$} & \multirow[t]{2}{*}{0,037} \\
\hline$>70$ & 28 & 75,26 & 13,4 & & \\
\hline \multicolumn{5}{|l|}{ Pendidikan } & \\
\hline Tidak sekolah & 23 & 82,82 & 11,28 & \multirow{5}{*}{$11,51^{\mathrm{b}}$} & \multirow{5}{*}{0,021} \\
\hline SD & 28 & 75,02 & 12,25 & & \\
\hline SMP & 19 & 81,43 & 12,59 & & \\
\hline SMA & 14 & 86,74 & 12,77 & & \\
\hline Perguruan tinggi & 6 & 82,99 & 13,99 & & \\
\hline
\end{tabular}

Keterangan $: \mathrm{n}=$ jumlah; $\overline{\boldsymbol{x}}=$ rata-rata skor; $\mathbf{S D}=\operatorname{simpangan}$ baku; $\mathrm{a}=$ statistik $Z$ Mann-Whitney; $\mathrm{b}=$ statistik chi-kuadrat Kruskal-Wallis

Hasil Uji Mann-Whitney terbukti bahwa perbedaan jenis kelamin tidak terbukti dapat menjelaskan perbedaan skor kepuasan, sedangkan perbedaan usia dapat menjelaskan perbedaan skor kepuasan yang terjadi. Berdasarkan Uji Kruskal-Wallis terbukti bahwa perbedaan tingkat pendidikan dapat menjelaskan perbedaan skor kepuasan yang terjadi.
Berdasarkan hasil analisis regresi diperoleh hasil yaitu model pengaruh kualitas pelayanan pada kepuasan pasien lansia dapat diterima secara statistik $(F=55,876$; $\mathrm{p}<0,001)$. Variabel independen yang tidak terbukti bermakna secara statistik dan dikeluarkan dari model adalah dimensi kehandalan $(p=0,573)$ dan jaminan $(\mathrm{p}=0,328)$.

Tabel 3 Hasil Analisis Regresi Multivariabel

\begin{tabular}{|c|c|c|c|c|c|}
\hline Variabel & $\begin{array}{l}\text { WefisienRegresi } \\
\left(\begin{array}{l}\text { we } \\
(\mathcal{E})\end{array}\right.\end{array}$ & $\begin{array}{l}\text { Standard } \\
\text { Error }\end{array}$ & $\begin{array}{l}\text { Koefisi } \\
\text { Jalur }{ }^{(p) i n}\end{array}$ & Statistik-t & Nilai $\mathbf{p}$ \\
\hline Dimensi bukti fisik & 0,32 & 0,07 & 0,42 & 4,59 & $<0,001$ \\
\hline Dimensi ketanggapan & 0,19 & 0,06 & 0,28 & 3,44 & 0,001 \\
\hline Dimensi perhatian & 0,20 & 0,09 & 0,25 & 2,30 & 0,023 \\
\hline
\end{tabular}

Keterangan: $r$-multiple $=0,797 ; \mathrm{p}<0,001 ;$ variabel yang tidak bermakna $=$ kehandalan dan jaminan; dependen: kepuasan pasien lansia

Hasil analisis pada Tabel 3 menunjukkan bahwa dimensi bukti fisik, ketanggapan, dan perhatian mempunyai pengaruh yang bermakna secara statistik pada kepuasan pasien lansia sebesar $\left(0,797^{2} \times 100 \%=63,6 \%\right.$. Besarnya pengaruh dimensi bukti fisik pada kepuasan pasien lansia adalah 0,42 atau $\left(0,42^{2} \times 100 \%=17,64 \%\right.$. Besarnya pengaruh dimensi ketanggapan pada kepuasan pasien lansia adalah 0,28 atau $(0,28)^{2} \times 100 \%=7,84 \%$. Besarnya pengaruh dimensi perhatian pada kepuasan pasien lansia adalah 0,25 atau $(0,25)^{2} \mathrm{x}$ $100 \%=6,25 \%$. Merujuk pada hasil analisis tersebut dapat ditunjukkan bahwa besar pengaruh dari faktor lainnya (yang tidak diamati) adalah $(100-63,6) \%=36,4 \%$.

Berdasarkan kajian teori sebelumnya bahwa jika layanan Puskesmas Santun Lansia ditingkatkan, maka dapat memuaskan pasien lansia terhadap pelayanan kesehatan yang diselenggarakan pemerintah. Secara teoritis, pasien yang puas akan memaksimalkan adanya pemanfaatan pelayanan kesehatan. Pemanfaatan pelayanan kesehatan merupakan bagian perilaku kesehatan berupa kegiatan yang berkaitan dengan upaya mempertahankan dan meningkatkan kesehatan. Salah satu upaya pemanfaatan pelayanan kesehatan ikut ditentukan oleh 
kualitas pelayanan, yaitu pelayanan yang dipersepsikan baik dan memuaskan, apabila dirasakan sesuai dengan yang diharapkan. ${ }^{27}$

\section{Pembahasan}

Upaya pemanfaatan pelayanan kesehatan salah satunya ditentukan oleh kualitas pelayanan, yaitu pelayanan yang dipersepsikan baik dan memuaskan, apabila dirasakan sesuai dengan yang diharapkan. ${ }^{4}$ Pelayanan kesehatan kepada pasien lansia secara rinci telah digariskan oleh pemerintah dalam bentuk pedoman penyelenggaraan Puskesmas Santun Lansia. ${ }^{22}$ Namun pada pelaksanaannya, program ini belum dilaksanakan sesuai dengan pedoman tersebut, karena terkendala permasalahan jumlah tenaga kesehatan yang tersedia di puskesmas dan minimnya sumber dana untuk membiayai jalannya program. Sehingga jika dikaitkan dengan harapan responden terhadap pelayanan Puskesmas Santun Lansia yang seharusnya mereka terima, diperoleh sebuah kesenjangan antara harapan dan kenyataan pelayanannya.

Secara keseluruhan kualitas pelayanan Puskesmas Santun Lansia mempunyai kenyataan layanan yang cukup baik. Harapan yang besar responden terhadap pelayanan yang berkualitas tercermin pada besarnya harapan pada setiap dimensinya. Dimensi pelayanan yang mempunyai harapan terbesar ada pada dimensi kehandalan, sedangkan harapan terkecil ada pada dimensi perhatian. Hal ini mengindikasikan kepercayaan pasien lansia kepada kualitas pelayanan puskesmas yang diharapkan mampu menyembuhkan berbagai gangguan kesehatannya. Meskipun memiliki kenyataan yang belum sesuai harapan, namun seluruh dimensi kualitas pelayanan telah dipersepsikan cukup baik dalam kenyataan layanannya.

Puskesmas Santun Lansia mempunyai ciriciri sebagai berikut: 1) memberikan pelayanan yang baik, berkualitas, dan sopan; 2) memberikan kemudahan dalam pelayanan kepada lansia; 3) memberikan keringanan atau penghapusan biaya pelayanan kesehatan bagi lansia dari keluarga miskin atau tidak mampu; 4) memberikan dukungan/bimbingan pada lansia dalam memelihara dan meningkatkan kesehatannya, agar tetap sehat mandiri; 5) melakukan pelayanan secara proaktif untuk dapat menjangkau sebanyak-banyaknya sasaran lansia yang ada di wilayah kerja puskesmas; serta 6) melakukan kerjasama dengan lintas program dan lintas sektor terkait di tingkat kecamatan dengan asas kemitraan, untuk bersama-sama melakukan pembinaan dalam rangka meningkatkan kualitas hidup lansia. ${ }^{4,22}$

Hasil penelitian membuktikan bahwa kualitas pelayanan Puskesmas Santun Lansia signifikan berpengaruh positif pada kepuasan pasien lansia. Model akhir ini menunjukkan bahwa dimensi bukti fisik, ketanggapan, dan perhatian berpengaruh terhadap kepuasan pasien lansia sebesar 63,6\%; sedangkan yang tidak terbukti secara statistik berpengaruh adalah dimensi kehandalan dan jaminan.

Hasil ini secara substansi konsisten dengan hasil penelitian Bamfo dan Hagin $^{29}$ bahwa hubungan antara lansia dan tenaga kesehatan saat menerima pelayanan kesehatan merupakan inti kepuasan pasien lansia.Kepercayaan dan komunikasi yang baik merupakan kunci hubungan yang dapat menciptakan kepuasan pasien lansia.Sikap perhatian dari para tenaga kesehatan saat memberikan pelayanan terhadap pasien lansia mampu menumbuhkan kenyamanan, perasaan aman, dan kepuasan terhadap layanan. Hasil penelitian ini juga konsisten dengan yang ditemukan Kuzma dkk. ${ }^{30}$ Pengukuran kepuasan dilakukan terhadap aspek perilaku dan kinerja tenaga kesehatan dalam pelayanan, ranking layanan yang disediakan, aksesibilitas, perlakukan, adanya penyuluhan kesehatan, kelengkapan sarana serta prasarana, ketersediaan obat, dan kepercayaan terhadap tenaga kesehatan dalam pelayanan kesehatan. Aspek perilaku tenaga kesehatan diduga menjadi penyebab tingginya tingkat kepuasan pasien.Hasil penelitian tersebut konsisten dengan hasil penelitian Aldana dkk. ${ }^{31}$ yang mengukur kepuasan pasien terhadap kualitas pelayanan kesehatan di daerah luar perkotaan Bangladesh di tahun 2001.Hasilnya menunjukkan bahwa kepuasan pasien tertinggi diperoleh pada aspek perilaku dari tenaga kesehatan dalam melayani pasien. Aspek ini dipersepsikan pasien sebagai aspek yang lebih penting dibandingkan kompetensi teknis tenaga kesehatan.Kemampuan puskesmas dalam memberikan kepuasan kepada pasien tidak terlepas dari kenyamanan fisik tempat pelayanan, penampilan petugas, daya tanggap, dan perhatian pemberi layanan. Kualitas dipersepsikan baik, apabila petugas memiliki perhatian, rasa menghargai, peka serta memiliki kemampuan secara cepat dan tepat dalam 
menanggapi keluhan maupun memberikan informasi sesuai kebutuhan pasien.

Berdasarkan teori dan hasil analisis, dapat disimpulkan bahwa peningkatan/penurunan kepuasan pasien lansia terhadap pelayanan Puskesmas Santun Lansia tampak jelas dipengaruhi oleh kualitas pelayanan yang diterimanya. Sejumlah faktor yang tidak dimasukkan kedalam penelitian terbukti mempunyai kontribusi yang cukup besar terhadap perubahan kepuasan, yaitu sebesar $36,4 \%$. Hal ini menunjukkan bahwa kepuasan pasien lansia sesungguhnya tidak terlepas dari proses interaksi lansia dengan lingkungan sekitarnya. Proses interaksi ini dapat menghasilkan peningkatan atau dapat juga mengakibatkan penurunan kepuasan.

Hasil penelitian menunjukkan bahwa skor kepuasan pasien lansia memiliki perbedaan yang signifikan secara statistik berdasarkan perbedaan karakteristik usia dan pendidikan. Hal ini bukti bahwa perbedaan usia dan pendidikan pada kelompok lansia dapat menjelaskan perbedaan skor kepuasan yang terjadi. Merujuk pada nilai skor kepuasan rata-rata yang lebih tinggi pada kelompok usia responden 60-70 tahun dibandingkan dengan kelompok usia $>70$ tahun menunjukkan bahwa semakin bertambahnya usia responden maka sulit untuk merasakan kepuasan pada pelayanan puskesmas. Hasil ini konsisten dengan hasil penelitian yang dilakukan oleh Flett $\mathrm{dkk}^{21}$ menunjukkan bahwa variabel usia mempunyai hubungan dengan peningkatan kepuasan lansia terhadap pelayanan kesehatan yang diterima. Hasil ini juga konsisten dengan hasil penelitian yang dilakukan Howse $^{24}$ di Inggris menunjukkan bahwa terdapat hubungan yang signifikan antara kelompok usia dengan kepuasan lansia terhadap layanan kesehatan. Para lansia ini menunjukkan mudah mensyukuri kesehatan yang dirasakannya setelah memperoleh layanan kesehatan. Pembahasan dapat disimpulkan bahwa kualitas pelayanan Puskesmas Santun Lansia di Kabupaten Bogor berpengaruh positif terhadap kepuasan pasien lansia. Secara khusus diperoleh simpulan bahwa dimensi bukti fisik, kehandalan, ketanggapan, jaminan, dan perhatian, yang diterima oleh pasien lansia dalam pelayanan Puskesmas Santun Lansia, dipersepsikan cukup baik.Kepuasan pasien lansia terhadap pelayanan Puskesmas Santun Lansia belum 100\%, karena pelayanan yang diterima belum memenuhi harapan pasien untuk seluruh dimensi.Perbedaan jenis kelamin tidak signifikan berbeda pada kepuasan pasien lansia. Sedangkan perbedaan usia dan pendidikan, signifikan berbeda pada kepuasan pasien lansia. Dimensi bukti fisik, ketanggapan, dan perhatian, signifikan berpengaruh positif pada kepuasan pasien lansia.Sedangkan dimensi ketahanan dan jaminan tidak signifikan berpengaruh pada kepuasan.

Diperlukan penelitian lebih lanjut untuk menjelaskan peran dari faktor-faktor relevan lain yang diduga berperan pada perubahan (peningkatan/penurunan) kualitas pelayanan Puskesmas Santun Lansia dengan memperhatikan aspek internal dan eksternal petugas, misalnya motivasi petugas puskesmas dan iklim kerja Puskesmas Santun Lansia. Hal ini terkait dengan bukti bahwa terdapat pengaruh dari faktor yang lain (di luar dimensi kualitas pelayanan) pada kepuasan pasien lansia. Diperlukan penelitian lebih lanjut untuk mengidentifikasi lebih dalam mengenai kualitas pelayanan Puskesmas Santun Lansia dengan mengaitkannya pada implikasi kebijakan pemerintah terhadap pengembangan program Puskesmas Santun Lansia. Hal ini disebabkan karena beberapa permasalahan dalam pelayanan Puskesmas Santun Lansia terkait dengan keterbatasan jumlah tenaga petugas dan dukungan dana.

Secara praktis, hasil ini dapat dijadikan informasi awal bagi pemerintah untuk mulai meningkatkan alokasi anggaran pada pembangunan sarana dan prasarana di Puskesmas Santun Lansia.Hal ini merujuk kepada fakta bahwa semakin tua lansia maka semakin menuntut tersedianya sarana yang membantu kebutuhan mereka.Sedangkan semakin tinggi tingkat pendidikan lansia, cenderung merasa lebih puas terhadap pelayanan Puskesmas Santun Lansia. Hasil ini mengindikasikan suatu kebutuhan untuk pelatihan komunikasi bagi para tenaga kesehatan yang ditugaskan di Puskesmas Santun Lansia.Sehingga petugas nantinya dapat berkomunikasi dengan bahasa yang mudah dipahami oleh pasien lansia yang berpendidikan rendah.Diperlukan penambahan jumlah petugas untuk Puskesmas Santun Lansia.Hal ini terkait dengan pelayanan puskesmas yang belum sesuai dengan harapan pasien lansia. Pemerintah diharapkan lebih serius untuk memberikan dukungan dana dan menambah jumlah petugas untuk Puskesmas Santun Lansia. Kesenjangan 
yang terjadi lebih disebabkan karena keterbatasan Puskesmas Santun Lansia dari aspek dana dan tenaga petugas, sehingga pelayanan terhadap pasien lansia menjadi tidak sesuai dengan yang ditetapkan oleh pemerintah.

\section{Simpulan}

Kualitas pelayanan Puskesmas Santun Lansia dalam dimensi servqual (bukti fisik, kehandalan, ketanggapan, jaminan, dan perhatian) telah dipersepsikan memiliki kenyataan cukup baik, walaupun kualitas pelayanan yang diterima masih belum memenuhi harapan.

\section{Daftar Pustaka}

1. Undang-Undang Kesehatan Republik Indonesia Nomor 36 Tahun 2009..

2. Kemenkes RI. Menuju tua: sehat, mandiri dan produktif. "Kesehatan yang baik memperpanjang usia dan kehidupan". Jakarta: Kementerian Kesehatan Republik Indonesia; 2012.

3. Susanto A. Jumlah lansia Indonesia, lima besar terbanyak di dunia. Berita Liputan6. Minggu 24 Maret 2013.

4. Kemenkes RI. Gambaran kesehatan lanjut usia di Indonesia. Buletin jendela data dan informasi kesehatan. Semester I 2013. Jakarta: Kementerian Kesehatan Republik Indonesia; 2013.

5. Komnas Lansia RI. Profil penduduk lanjut usia 2009. Jakarta: Komisi Nasional Lanjut Usia Republik Indonesia; 2010.

6. Depkes RI. Pedoman Puskesmas Santun UsiaLanjut bagi petugas kesehatan. Jakarta: Dirjen BinaKesehatan Masyarakat Direktorat Kesehatan Keluarga Departemen Kesehatan Republik Indonesia; 2003.

7. Dinkes Provinsi Jawa Barat. Profil kesehatan Jawa Barat 2012. Bandung: Dinas Kesehatan Provinsi Jawa Barat; 2013.
8. Dinkes Kabupaten Bogor. Profil kesehatan Kabupaten Bogor 2012. Bandung: Dinas Kesehatan Kabupaten Bogor; 2013.

9. Notoatmodjo S. Ilmu perilaku kesehatan. Jakarta: Rineka Cipta; 2010.

10. Notoatmojo S. Promosi kesehatan teori \& aplikasi. Jakarta: Rineka Cipta; 2010.

11. British Geriatric Society. Quality care for older people with urgent \&emergency care needs. The Silver Book. 2012. (diunduh 29 Juli 2013). Tersedia dari: www.bgs.org.uk/campaigns/silverb/silver_book_ complete.pdf.

12. MacAdam M. Frameworks of integrated care for the elderly: systematic review - 2008. CPRN Research Report. April 2008. Ontario: Canadian Policy Research Network; 2008. (diunduh 29 Juli 2013). Tersedia dari: www.cprn.org/documents/49813_EN.pdf.

13. Lynch M, Workman D, Shipp B, Gill G, Edwards L, Rosecranz N, et.al. Elderly services in health centers: aguide to address unique challenges of caring for elderly people with disabilities, frailty, and other special needs. Wisconsin USA: National Association of Community Helath Centers; 2008.

14. Sodani PR,Sharma K. Assessing patient satisfaction for investigative services at public hospitals to improve quality of services. Nat $\mathbf{J}$ Comm Med. 2011Oct-Des;2(Issue 3):404-8.

15. Raftopoulos V. A grounded theory for patient's satisfaction with quality of hospital care. Icus Nurs Web J. 2005 June; Issue 22:136-9.

16. Shaikh BT, Mobeen N, Azam SI, Rabbani F. Using SERVQUAL For assessing and improving patient satisfaction at a rural health facility in Pakistan. Eastern Mediterranean Health J. 2008;14(2):44755

17. Haryanto JO, Olivia. Pengaruh faktor pelayanan rumah sakit, tenaga medis, dan kualitas pelayanan rumah sakit terhadap intense pasien Indonesia untuk berobat di Singapura. J Ekonomi Bisnis. 2009;14(2):144-51. 